\title{
Sistem Switch Monitoring Berbasis Web
}

\author{
Sandi Prasetyaningsih ${ }^{1}$, Ahmad Kussyairi ${ }^{2}$, \\ ${ }^{1}$ Politeknik Negeri Batam \\ Multimedia and Networking Engineering Program \\ Jln. Ahmad Yani, Batam Centre, Batam 29461, Indonesia \\ E-mail: sandi@polibatam.ac.id, kussyairi@gmail.com
}

\begin{abstract}
Abstrak
Dokumentasi switch pada PT ABC masih dilakukan secara manual oleh departemen IT. Sistem dokumentasi data yang dilakukan secara manual ini dapat menimbulkan beberapa masalah, antara lain munculnya data berulang. Selain itu, monitoring yang dilakukan secara manual akan memakan waktu jika pihak tertentu ingin melakukan pencarian data. Metode waterfall digunakan dalam pengembangan sistem monitoring switch berbasis web. Ada lima tahapan yang digunakan dalam pengembangan dengan metode waterfall, yaitu analisis, desain, pengkodean, pengujian, dan penerapan program serta pemeliharaan. Pengujian dari sistem monitoring menggunakan metode black box yang dilakukan pada sistem dengan melihat spesifikasi fungsional tanpa menguji desain dan pengkodean. Hasil perancangan, implementasi, dan pengembangan, sistem switch monitoring berbasis web berhasil dibuat dengan memiliki beberapa fitur seperti menambah switch, edit switch, hapus switch, detail switch, dan manajemen user.
\end{abstract}

Kata kunci: Switch, Monitoring, Metode Waterfall, Metode Black box

\begin{abstract}
Switch documentation monitoring at PT ABC is executed manually by IT department. This current system occurs some problems such us data redundant. Moreover, manual documentation also takes time as well as it brings user spend more times when they are trying to look for certain data. Waterfall method is used to generate switch monitoring on website based. There are five steps that are using to develop the system, such as analyzing, designing coding, testing, and implementing code as well as maintaining. During the testing, black box method is utilizing to obtain certain specification of the system. The result of the design, implementation, dan evolvement of switch system monitoring by using web is successfully implemented. This system has several functions that can be used by user, namely add switch, edit switch, and delete switch, detail switch, and user management control.
\end{abstract}

Keywords: Integrasi, margin

\section{Pendahuluan}

PT ABC merupakan perusahaan yang bergerak dibidang semikonduktor pembuatan dan perakitan Integrated Circuit (IC). Perusahaan ini didirikan pada tahun 2002 dan merupakan cabang dari perusahaan PT ABC yang berada di Munich, Jerman. Departemen IT pada perusahaan ini terdiri dari dua bagian, yaitu IT Office dan IT Client Service. Departemen IT Office merupakan departemen yang bertugas menangani masalah data center, jaringan dan perangkat jaringan lainnya.

Dalam melakukan proses bisnisnya, departemen IT berhadapan dengan beberapa kendala. Salah satunya adalah pengolahan data monitoring switch dan pelaporan data switch yang masih dilakukan secara manual. Pendataan dilakukan dengan mencatat data laporan dari label switch, ip, dan port yang digunakan pada suatu device menggunakan Microsoft Excel, sehingga dalam melakukan pendataan sering mengalami terjadinya redundancy data (data ganda). Hal ini tentu saja akan menimbulkan masalah-masalah lain jika terus dibiarkan. Salah satu akibat dari data yang teredudansi adalah data yang ada menjadi tidak konsisten [1]. Selain itu, sistem pengolahan data yang masih manual akan membuat sistem monitoring tidak efektif dan efisien. Sebagai contoh, jika diperlukan data dalam waktu cepat, hanya pihak yang menyimpan data yang dapat melihat sedangkan kondisi yang terjadi dalam keadaa darurat.

Berdasarkan permasalahan yang telah disebutkan di atas, penelitian ini akan fokus pada perancangan monitoring data switch berbasis web. 


\section{Metode Penelitian}

Dalam melakukan penelitian, metode yang digunakan untuk perancangan sistem adalah metode SDLC; waterfall. Pada metode perancangan waterfall, tahap demi tahap yang dilalui harus menunggu selesainya tahap sebelumnya dan berjalan berurutan. Sebagai contoh tahap desain harus menunggu selesainya tahap sebelumnya yaitu tahap requirement [2]. Metode ini menyediakan beberapa pendekatan alur hidup perangkat lunak secara berurutan dimulai dari proses analisa, desain, pengkodean, pengujian, dan penerapan program pemeliharaan [3].

Menurut [4], metode waterfall memiliki beberapa kelebihan dibandingan metode pengembangan perangkat lunak lainnya, diantara lain:

1. Kualitas produk yang dihasilkan lebih baik karena tahapan eksekusinya dilakukan secara bertahap.

2. Proses pengembangan dilakukan dalam fase satu per satu sehingga dapat meminimalis terjadinya kesalahan.

3. Dokumen pengembangan sistem terorganisir karena setiap Langkah harus diselesaikan terlebih dahulu sebelum masuk keproses berikutnya.

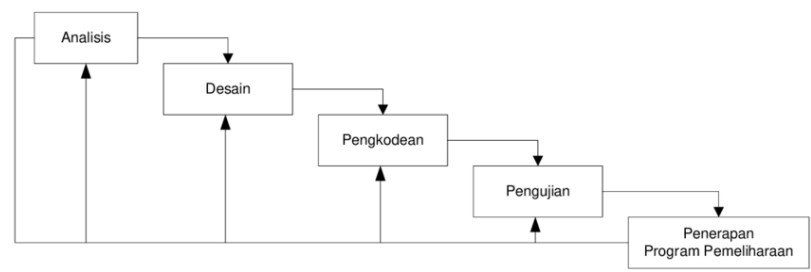

Gambar 1: Ilustrasi Metode Waterfall

Gambar 1 merupakan ilustrasi dari tahapan metode waterfall. Setiap prosesnya memiliki peran yang sangat penting dalam pembuatan sebuah perangkat lunak.

\section{A. Analisa Perangkat Lunak}

Pada tahan ini, pembuat sistem harus sudah melakukan identifikasi kebutuhan perangkat lunak yang dibutuhkan untuk pengembangan dan user.

\section{B. Desain}

Desain perangkat lunak fokus pada desain pembuatan program yang meliputi deskripsi umum sistem, perancangan sistem, dan rancangan antarmuka. Pada proses desain ini, pengembang mencoba mengkonversi kebutuhan analisis perangkat lunak menjadi sebuah program yang akan digunakan pada tahap selanjutnya.

C. Pengkodean

Setelah melakukan identifikasi desain perangkat lunak, proses yang dilakukan selanjutnya adalah mengubah desain menjadi bahasa pemograman. Dalam proses pengkodean akan banyak ditemukan trial dan error karena penyesuaian program dan kebutuhan perangkat lunak.

\section{Pengujian}

Untuk memastikan apakah program yang dibuat sudah sesuai dengan kebutuhan perangkat lunak atau belum, dibutuhkan sebuah proses pengujian untuk semua fungsi yang terdapat pada program. Proses pengujian ini biasanya akan dilakukan lebih dari satu kali sampai dengan program dapat berjalan sesuai kebutuhan.

Pengujian pada sebuah perangkat lunak sangatlah penting. Berdasarkan [5], ada beberapa tujuan dari pengujian perangkat lunak, yaitu:

1. Kesalahan pada perangkat lunak dapat dilihat pada saat program dijalankan.

2. Pengujian dilakukan untuk mengetahui kesalahan yang belum teridentifikasi.

3. Pengujian dikatakan berhasil jika dapat memunculkan kesalahan yang belum teridentifikasi.

\section{Penerapan program dan pemeliharaan}

Ketika sudah digunakan oleh user, error mungkin saja akan ditemukan karena variasi user dan tidak terdeteksi pada saat pengujian. Proses pemeliharaan perangkat lunak dapat dimulai dari proses analisa; dilakukan beberapa perubahan tapi tidak untuk membuat sebuah perangkat lunak yang baru.

\section{Hasil dan Pembahasan}

\subsection{Deskripsi Umum Sistem}

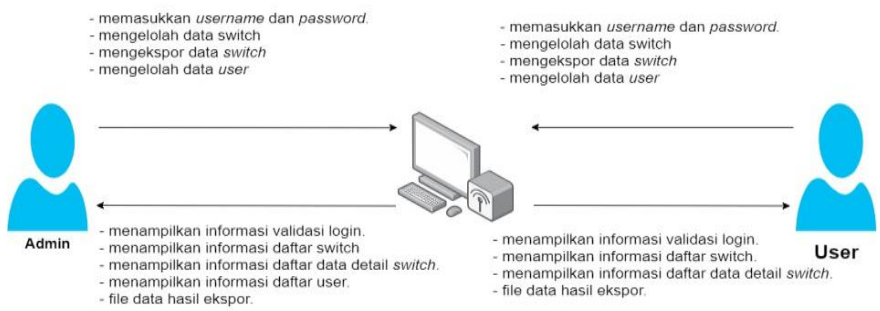

Gambar 2: Deskripsi Umum Sistem

Gambar 2 menjelaskan tentang sistem network port monitoring menangani pengelolaan data switch. Terdapat dua level user, yaitu admin dan user. Admin memiliki hak akses dalam mengelolah seluruh data yang meliputi data switch, dan data user. Sedangkan user hanya dapat mengelolah data switch. Admin dan user dapat melakukan ekspor file ke dalam bentuk 
excel. Sistem ini hanya dikelolah oleh admin dan user dalam memonitoring data switch.

\subsection{Perancangan Sistem}

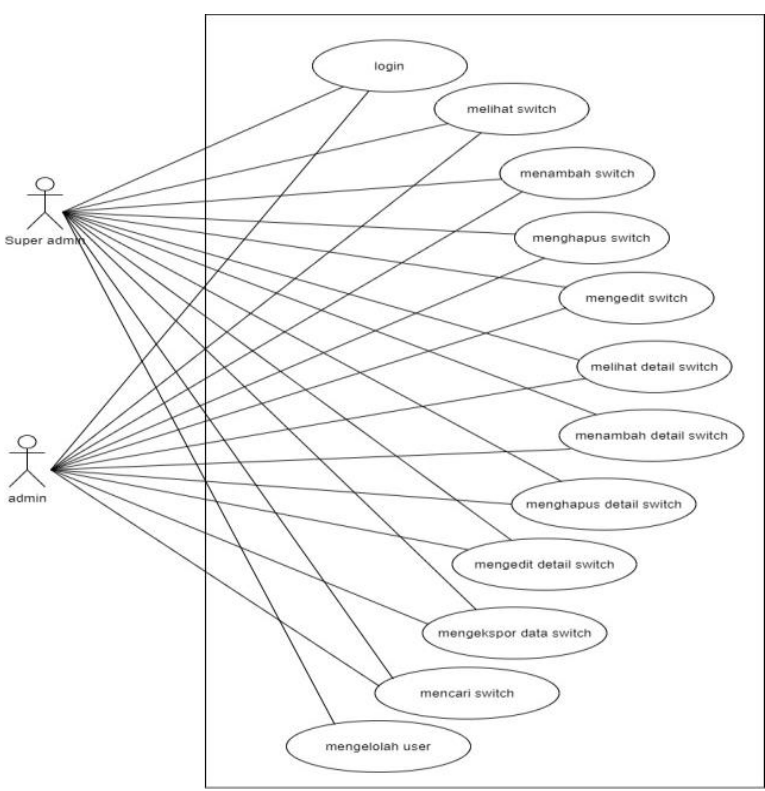

Gambar 3: Perancangan Sistem

Sistem networking monitoring berbasis web pada PT ABC memiliki dua user seperti yang disajikan pada gambar 3. Super admin harus melakukan login terlebih dahulu agar dapat menjalankan beberapa fungsi seperti melihat switch, menambah switch, menghapus switch, mengedit switch, melihat detail switch, menambah detail switch, menghapus detail switch, menghapus detail switch, mengedit detail switch, mengekspor detail switch, mencari switch, dan mengelola user. Admin memiliki fitur yang hamper sama dengan super admin kecuali tidak bisa melakukan pengelolaan user.

\subsection{Perancangan Basis Data}

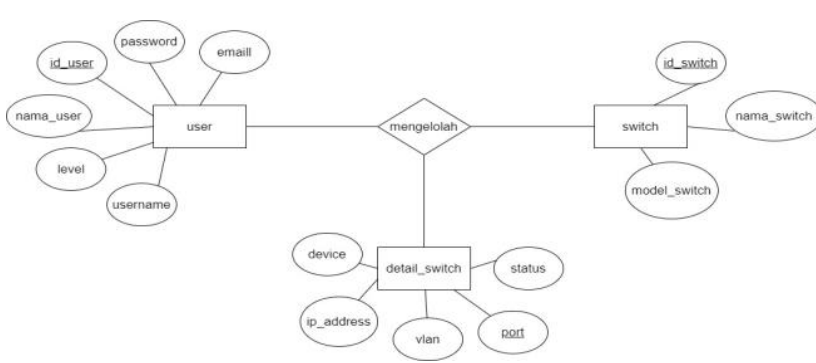

Gambar 4: Perancangan Basis Data

Pada perancangan basis data yang disajikan pada gambar 4, ada tiga entitas yang berbeda, yaitu user, detail_switch dan switch. Masing-masing entitas memiliki primary key yang berbeda, yaitu id_user, id_switch, dan port.

\subsection{User Interface}

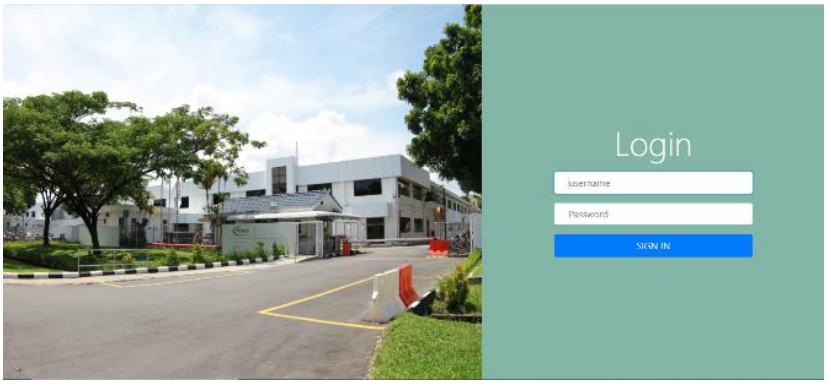

Gambar 5: Halaman Login

Pada halaman login, admin dan user menggunakan halaman yang sama. Pengguna harus memasukkan username dan password yang sebelumnya sudah didaftarkan ke sistem. Kemudian menekan sign in untuk masuk kesistem. Desain antarmuka login dapat dilihat pada gambar 5 .

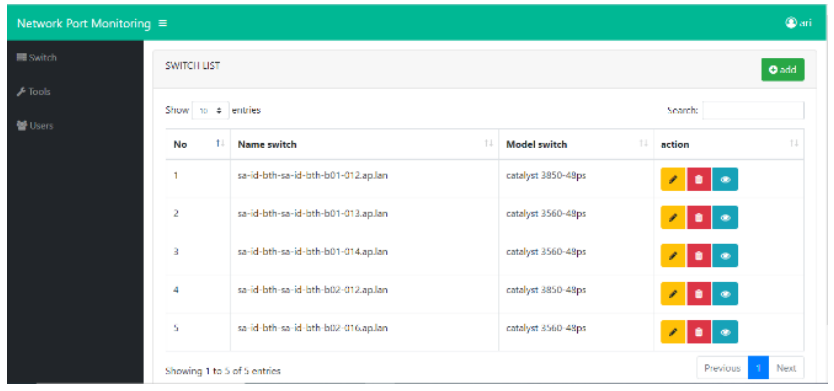

Gambar 6: Halaman List Switch

Pada halaman list switch, pengguna baik itu admin ataupun user dapat melihat data-data dari switch yang data halamannya berisikan nama switch, model switch, dan beberapa action. Desain antarmuka list switch dapat dilihat pada gambar 6 .

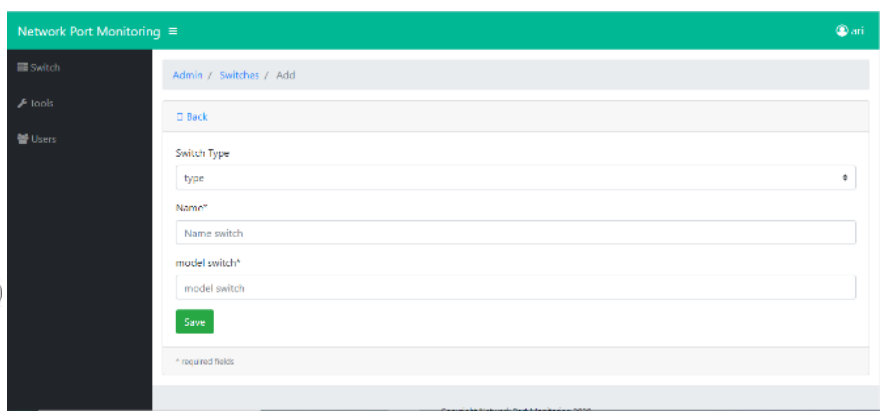

\section{Gambar 7: Halaman Tambah Switch}

Pada halaman tambah switch pengguna baik itu admin ataupun user dapat menambahkan data switch dengan memasukkan nama switch dan model switch. Desain antarmuka dapat dilihat pada gambar 7 . 


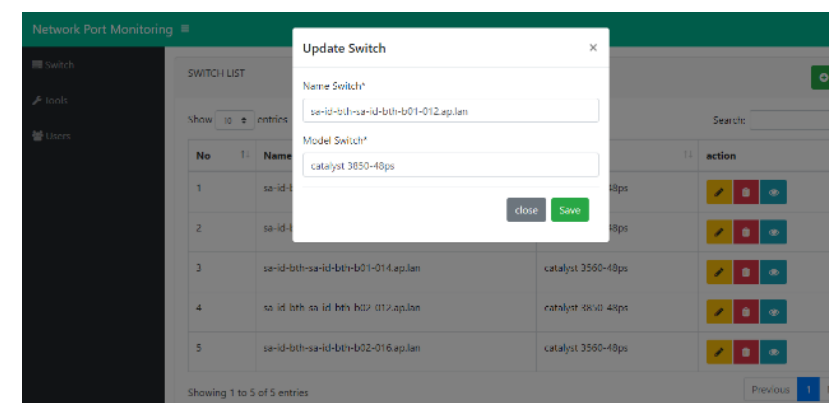

Gambar 8: Halaman Edit Switch

Pada halaman edit switch, pengguna baik itu admin ataupun user dapat melalukan update data pada data pada list switch dengan memasukkan data baru. Desain antarmuka halaman edit switch dapat dilihat pada gambar 8 .

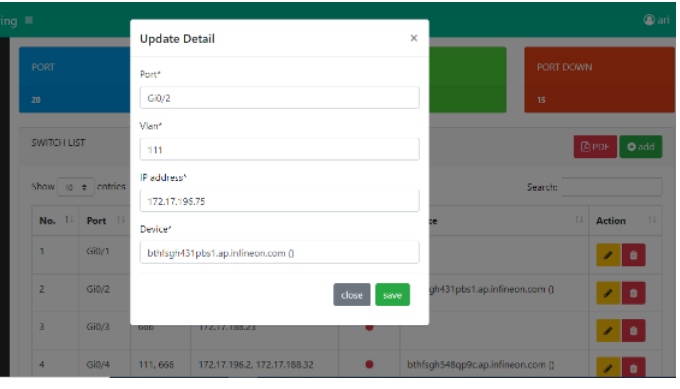

Gambar 11: Halaman Edit Detail Switch

Pada halaman edit detail switch, pengguna baik itu admin ataupun user dapat meng-update data port switch dengan memasukkan data baru dan menyimpannya. Desain antarmuka halaman edit detail switch dapat dilihat pada gambar 11 .

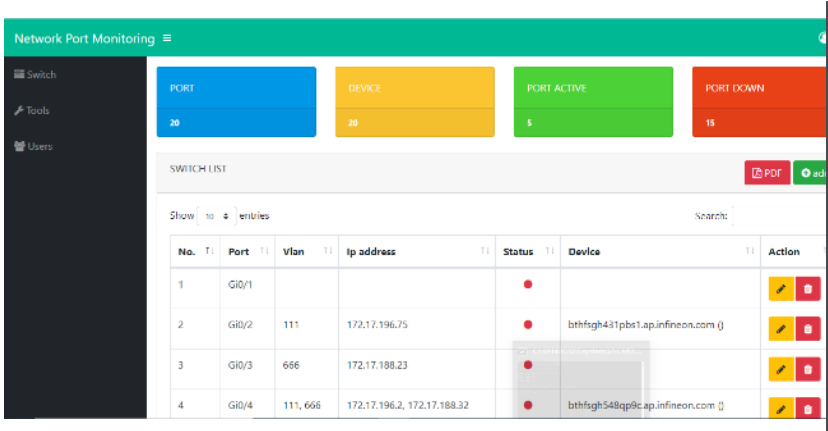

Gambar 9: Halaman Detail Switch

Pada halaman detail switch, pengguna baik itu admin ataupun user dapat melihat data port dari switch. halaman yang berisikan informasi dari switch yang berisikan beberapa action. Desain antarmuka dapat dilihat pada gambar 9 .

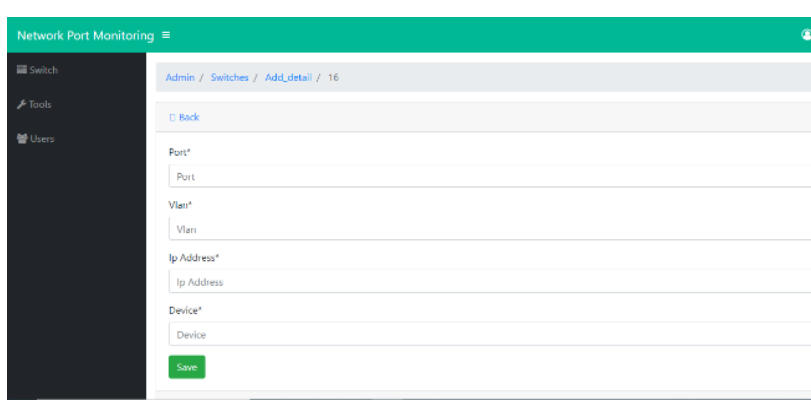

Gambar 10: Halaman Tambah Detail Switch

Halaman tambah detail switch, pengguna baik itu admin ataupun user dapat menambah data detail switch dengan memasukkan form data pada halaman detail switch. Desain antarmuka halaman tambah detail switch dapat dilihat pada gambar 10 .

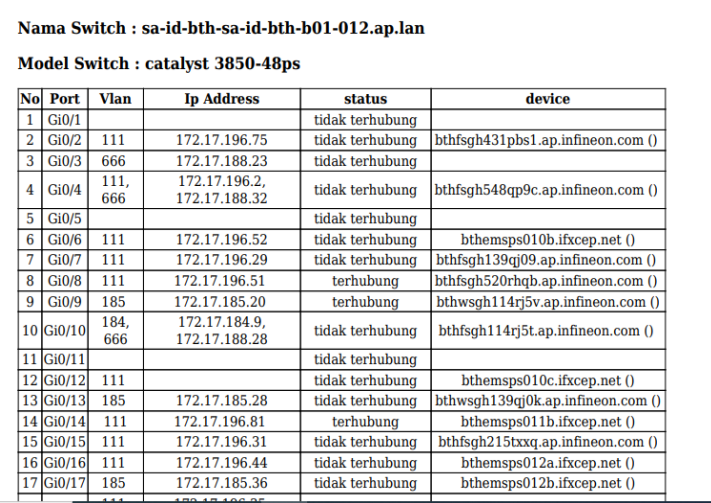

Gambar 12: Ekspor Switch

Ekspor data dapat dilakukan oleh admin maupun user. Dengan menekan ikon pdf pada detail switch maka akan menyajikan data dalam bentuk pdf. Desain hasil ekspor detail switch dapat dilihat pada Gambar 12.

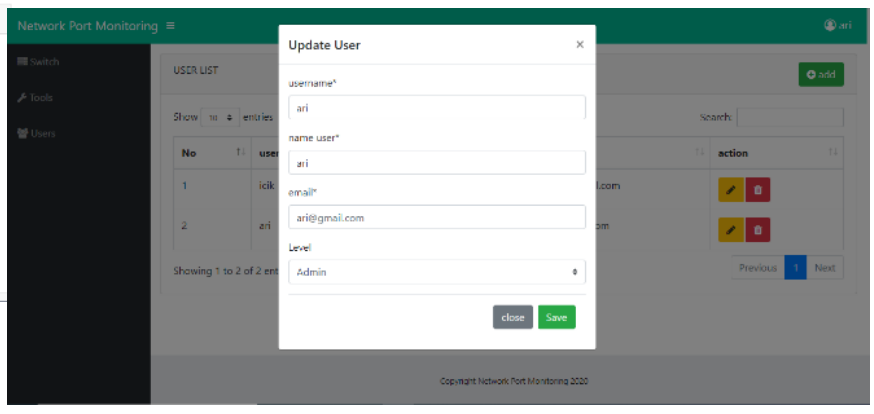

Gambar 13: Halaman Mengelola User

Pada halaman mengelola user, admin dapat meng-update langsung data dari user dengan memasukkan data dan menyimpannya. Desain antarmuka halaman edit user dapat dilihat pada gambar 13 . 
TABLE 1

PENGUJiAn SISTEM

\begin{tabular}{|c|c|c|c|c|}
\hline No & Nama Proses & $\begin{array}{l}\text { Skenario } \\
\text { Uji }\end{array}$ & Target & Validasi \\
\hline \multirow[t]{2}{*}{1} & \multirow[t]{2}{*}{ Login } & $\begin{array}{l}\text { Username } \\
\text { dan } \\
\text { password } \\
\text { benar }\end{array}$ & $\begin{array}{l}\text { Login } \\
\text { berhasil dan } \\
\text { diarahkan } \\
\text { ke halaman } \\
\text { beranda }\end{array}$ & $\checkmark$ \\
\hline & & $\begin{array}{l}\text { Username } \\
\text { dan } \\
\text { password } \\
\text { salah }\end{array}$ & $\begin{array}{l}\text { Login gagal } \\
\text { dan } \\
\text { menampilk } \\
\text { an pesan } \\
\text { kesalahan }\end{array}$ & $\checkmark$ \\
\hline 2 & $\begin{array}{l}\text { Melihat data } \\
\text { switch }\end{array}$ & $\begin{array}{l}\text { Membuka } \\
\text { menu } \\
\text { switch }\end{array}$ & $\begin{array}{l}\text { Data switch } \\
\text { berhasil di } \\
\text { tampilkan }\end{array}$ & $\checkmark$ \\
\hline \multirow[t]{3}{*}{3} & \multirow[t]{3}{*}{$\begin{array}{l}\text { Menambah } \\
\text { data switch }\end{array}$} & $\begin{array}{l}\text { Mengisi } \\
\text { semua form } \\
\text { dengan } \\
\text { benar }\end{array}$ & $\begin{array}{l}\text { Data switch } \\
\text { berhasil } \\
\text { disimpan }\end{array}$ & $\checkmark$ \\
\hline & & $\begin{array}{ll}\text { Salah satu } \\
\text { form tidak } \\
\text { terisi }\end{array}$ & $\begin{array}{l}\text { Data switch } \\
\text { gagal } \\
\text { disimpan, } \\
\text { muncul } \\
\text { pesan } \\
\text { kesalahan }\end{array}$ & $\checkmark$ \\
\hline & & $\begin{array}{l}\text { Data switch } \\
\text { sama }\end{array}$ & $\begin{array}{l}\text { Data gagal } \\
\text { disimpan, } \\
\text { muncul } \\
\text { pesan } \\
\text { kesalahan }\end{array}$ & $\checkmark$ \\
\hline 4 & $\begin{array}{l}\text { Mengedit } \\
\text { data switch }\end{array}$ & $\begin{array}{l}\text { Mengubah } \\
\text { data pada } \\
\text { form }\end{array}$ & $\begin{array}{l}\text { Data switch } \\
\text { berhasil } \\
\text { disimpan }\end{array}$ & $\sqrt{ }$ \\
\hline 5 & $\begin{array}{l}\text { Melihat data } \\
\text { detail_switch }\end{array}$ & $\begin{array}{l}\text { Aktor } \\
\text { memilih } \\
\text { menu } \\
\text { switch }\end{array}$ & $\begin{array}{l}\text { Data detail } \\
\text { switch } \\
\text { berhasil } \\
\text { ditampilkan }\end{array}$ & $\checkmark$ \\
\hline \multirow[t]{2}{*}{6} & \multirow[t]{2}{*}{$\begin{array}{l}\text { Menambah } \\
\text { data } \\
\text { detail_switch }\end{array}$} & $\begin{array}{l}\text { Mengisi } \\
\text { form } \\
\text { dengan } \\
\text { benar }\end{array}$ & $\begin{array}{l}\text { Data detail } \\
\text { switch } \\
\text { berhasil } \\
\text { disimpan }\end{array}$ & $\checkmark$ \\
\hline & & \begin{tabular}{ll}
\multicolumn{2}{l}{ Mengisi } \\
data pada \\
port yang \\
sama
\end{tabular} & $\begin{array}{l}\text { Data gagal } \\
\text { disimpan, } \\
\text { muncun } \\
\text { pesan } \\
\text { kesalahan }\end{array}$ & $\checkmark$ \\
\hline 7 & $\begin{array}{l}\text { Mengedit } \\
\text { data } \\
\text { detail_switch }\end{array}$ & $\begin{array}{l}\text { Mengubah } \\
\text { data pada } \\
\text { form }\end{array}$ & $\begin{array}{l}\text { Data detail } \\
\text { switch } \\
\text { berhasil } \\
\text { disimpan }\end{array}$ & $\checkmark$ \\
\hline 8 & $\begin{array}{l}\text { Mengekspor } \\
\text { data switch }\end{array}$ & $\begin{array}{l}\text { Aktor } \\
\text { memilih } \\
\text { salah satu } \\
\text { data switch } \\
-> \\
\text { membuka } \\
\text { detail } \\
\text { switch }\end{array}$ & $\begin{array}{l}\text { Data switch } \\
\text { di export ke } \\
\text { pdf }\end{array}$ & $\sqrt{ }$ \\
\hline \multirow[t]{2}{*}{9} & \multirow[t]{2}{*}{$\begin{array}{l}\text { Mengedit } \\
\text { data } u s e r\end{array}$} & $\begin{array}{l}\text { Mengubah } \\
\text { data pada } \\
\text { form } \\
\text { dengan } \\
\text { isian benar }\end{array}$ & $\begin{array}{l}\text { Data user } \\
\text { berhasil } \\
\text { disimpan }\end{array}$ & $\checkmark$ \\
\hline & & $\begin{array}{l}\text { Menguba } \\
\text { data pada } \\
\text { form } \\
\text { dengan } \\
\text { isian salah }\end{array}$ & $\begin{array}{l}\text { Data user } \\
\text { gagal } \\
\text { disimpan, } \\
\text { muncul } \\
\text { pesan } \\
\text { kesalahan }\end{array}$ & $\sqrt{ }$ \\
\hline
\end{tabular}

\begin{tabular}{|l|l|l|l|c|}
\hline & $\begin{array}{l}\text { Menghapus } \\
\text { salah satu } \\
\text { data } \text { user }\end{array}$ & $\begin{array}{l}\text { Data user } \\
\text { berhasil di } \\
\text { hapus }\end{array}$ & $\checkmark$ \\
\hline
\end{tabular}

Pengujian sistem dilakukan setelah proses desain dan pengkodean selesai. Pengujian dilakukan untuk mengecek apakah sistem yang dibuat sudah sesuai dengan yang dibutuhkan atau belum. Hal ini dapat dilihat dari input dari user dan output yang dihasilkan oleh sistem. Metode black box digunakan dalam pengujian ini karena metode black box dilakukan pada sistem dengan melihat spesifikasi fungsional tanpa menguji desain dan pengkodean [6].

\section{Kesimpulan}

Berdasarkan hasil perancangan dan impelementasi sistem network monitoring dapat diambil beberapa kesimpulan, yaitu:

1. Sistem network monitoring berbasis web sudah berhasil dirancang dan diimplementasikan dibuktikan dengan pengujian sistem dengan menggunakan metode black box.

2. Sistem network monitoring telah mengimplementasi beberapa fitur mulai dari menambah, edit dan hapus switch, detail switch, dan manajemen user.

\section{Daftar Pustaka}

[1] Suharyanto, C.E., Chandra, J.E. and Gunawan, F.E., 2017. Perancangan Sistem Informasi Penggajian Terintegrasi Berbasis Web (Studi Kasus di Rumah Sakit St. Elisabeth). Jurnal Nasional Teknologi dan Sistem Informasi, 3(2), pp.225-232.

[2] Bangun Sistem Informasi Manajemen Arsip Rumah Sakit Bedah Surabaya Berbasis Web. Jurnal Sistem Informasi. No. 2. Vol. 3. 2338-137X.

[3] Sukamto, Ariani Rosa dan Shalahuddin, Muhamad. 2018. Rekayasa Perangkat Lunak Terstruktur Dan Berorientasi Objek. Informatika, Bandung.

[4] Wahid, A.A., 2020. Analisis Metode Waterfall Untuk Pengembangan Sistem Informasi. Jurnal Ilmu-Ilmu Informatika Dan Manajemen STMIK, October, pp.1-5.

[5] Rouf, A., 2012. Pengujian perangkat lunak dengan menggunakan metode white box dan black box. HIMSYATECH, 8(1).

[6] Nur, H., 2019. Penggunaan Metode Waterfall Dalam Rancang Bangun Sistem Informasi Penjualan. Generation Journal, 3(1), pp.1-10. 